\title{
Curve Number (CN) as Pressure Indicator of the Hydrological Condition under Global Warming Scenarios at a Local Scale in La Mojana Region, Colombia
}

\author{
Alvaro J. Zabaleta ${ }^{1}$, Teobaldis Mercado ${ }^{2 *}$, Jose Luis Marrugo ${ }^{3}$ and Jhon Jairo Feria Diaz ${ }^{4}$ \\ 'School of Engineering, University of Cordoba, 6th Avenue No. 76-103. Monteria, Cordoba, Colombia; \\ alvarozabaleta92@gmail.com \\ ${ }^{2}$ Agriculture Science School, University of Cordoba. 6th Avenue No. 76-103. Monteria, Cordoba, Colombia; \\ tmercado@correo.unicordoba.edu.co \\ ${ }^{3}$ Department of Chemistry, University of Cordoba. 6th Avenue No. 76-103. Monteria, Cordoba, Colombia; \\ joseluismarrugo@gmail.com \\ ${ }^{4}$ Department of Civil Engineering, University of Sucre, Cra. 28 \#5-267, Sincelejo, Colombia; \\ jhon.feria@unisucre.edu.co
}

\begin{abstract}
Objective: This research study analyzed hydrological surface behavior of the lower basin of the Cauca, San Jorge and Loba tributaries of the Magdalena River in the so-called La Mojana Region in northern Colombia. Methods/Analysis: To determine hydrological behavior of the basins under study, an analysis of vegetation cover was used as the most dynamic condition; its soil use and granulometry as the natural condition, regarding the hydrological pressure degree of the territory, as well as climatic behavior in the last 40 years in the area. Findings: Results show that cover and land use do not contribute favorably to basin hydrological regulation, considering that $45.9 \%$ have pasture cover, being this least favored hydrological regulation. Application/Improvements: $92.3 \%$ of the total study area $\left(21,650.2 \mathrm{~km}^{2}\right)$ shows curve numbers greater than 80 , so that there is a high hydrological pressure on the territory. At the meantime, temperature shows a $0.8^{\circ} \mathrm{C}$ increase, while Evapotranspiration (ET) and vapor density have increases of $50.6 \mathrm{~mm}$ and $0.7 \mathrm{~g} \mathrm{~m}^{-1}$ respectively.
\end{abstract}

Keywords: HSG, Hydrological Condition, Initial Abstraction

\section{Introduction}

Curve Number involves four fundamental aspects of land hydrological behavior in surface run off generation: 1. Hydrological soil group; 2. Use and treatment; 3. Vegetation cover and 4. Previous humidity ${ }^{1,2}$. $\mathrm{CN}$ is an empirical method developed by the Soil Conservation Service (SCS) of the United States, based on the abstrac- tion of an event for which the relationships between precipitation and actual runoff with the potential are considered equal $\frac{3-7}{3}$. That is:

$$
\frac{R}{S}=\frac{Q}{P-I_{a}} \quad \text { Equation } 1
$$


Where R corresponds to the water fraction retained in the soil after runoff has started; $\mathrm{S}$, the maximum retention potential; Q, the total runoff generated by a precipitation $\mathrm{P}$ and; $I_{a,}$ the fraction of precipitation retained.

Thus, in continuity principle, since $\mathrm{P} \geq 0.2 \mathrm{~S}$ (if $\mathrm{P} \leq$ $0.2 S ; \mathrm{Q}=0$ ), the total runoff is given by:

$$
Q=\frac{(P-0.2 S)^{2}}{P+0,8 S}
$$

Equation 2.

$\mathrm{CN}$ can then be defined as the degree of affectation to a soil infiltration, determining maximum retention potential, described numerically as:

$$
C N=\frac{25400}{254+5} \quad \text { Equation } 3 .
$$

Nonetheless, $\mathrm{CN}$ can be more easily determined than $S$, since a number between 0 and 100 can be assigned to the first term, according to characteristics defined initially, namely:

$$
S=\frac{25400}{C N}-254 \quad \text { Equation } 4 .
$$

Representing the maximum water retention measured in millimeters, by abstraction effect. This abstraction depends on soil retention capacity, linked to its granulometry; initial abstraction by plants; type of use and its moisture condition ${ }^{8}$.

\subsection{Hydrological Group}

$\mathrm{CN}$ is classified in four groups (A, B, C and D), representing soil runoff potential (low, moderately low, moderately high and high, respectively), according to granulometric properties expressed, in some cases, in their saturation hydraulics; directly influencing, by natural condition, infiltration capacity $\underline{3,9-12}$.

\subsection{Land Use and Treatment}

Land use and treatment basically refers to the soil coverage as the most dynamic parameter and its importance in the initial abstraction processes $\frac{13}{}$; for which forested cov- erings allow a better hydrological regulation by favoring capacity of soil moisture conservation due to accumulation of dead vegetable material, root penetration and others.

\subsection{Cover Hydrological Condition}

Cover hydrological condition consist of the cover fraction occupied by a land area for a particular cover type, naming as a poor condition, that for which less than $50 \%$ of the area is covered, regular between $50 \%$ and $75 \%$ and good with more than $75 \%$ cover $^{2}$.

\subsection{Antecedent Moisture Condition (AMC)}

AMC expresses the five days of precipitation prior to the occurrence of a storm, determining the runoff potential that may occur in an area between each storm and categorized in three basic conditions, $\mathrm{y}^{10}$. In which an accumulated precipitation in five previous days with values between 0-36 mm, 36-53 mm and greater than 53 $\mathrm{mm}$ define each of the conditions respectively ${ }^{2}$. Equation 3 defines $\mathrm{CN}$ for an $\mathrm{AMC}_{\mathrm{II}}$, so it is necessary to make an adjustment for the two remaining AMCs where:

$$
\begin{array}{cl}
C N_{I}=\frac{C N_{I I}}{2.3-0.013 C N_{I I}} & \text { Equation 5. } \\
C N_{I I I}=\frac{C N_{I I}}{0.43-0.0057 C N_{I I}} & \text { Equation 6. }
\end{array}
$$

\subsection{Hydrological Pressure and Climate}

Climatic behavior of an area determines, to a considerable extent, the hydrological dynamics of the territory, given that, it interferes directly in the hydrological condition, as well as the precipitation availability in terms of quantity and distribution as the main input in the surface runoff generation and water supply $\frac{14-21}{1}$. So that articulation of a zone climatic behavior in the analysis of the area's hydrological condition is indispensable.

In these terms, global warming is a reality 22,23 . Nonetheless, models developed for surface heating identification are designed, mostly, to be applied regionally, not 
showing in detail a certain territory climatic behavior $\stackrel{24-28}{ }$, limiting the hydrological behavior analysis of small basins with its climatic component and making it necessary to use models that allow studying the phenomenon on a local scale. Trend analysis of air temperature T, vapor density $d_{v}$ and evapotranspiration of the soil-vegetation interface ET, turn out to be indicators of global warming on a local scale for areas with elevated temperature and relative humidity ${ }^{29}$; suggesting use of these variables in the of global warming identification at the local level in tropical zones.
This research analyzed the hydrological behavior in the La Mojana Region, in the North of Colombia, using the $\mathrm{CN}$ as an indicator of the degree of hydrological pressure of the territory under the manifestation of global warming on a local scale.

\section{Materials and Methods}

\subsection{Study Area}

La Mojana is geographically located in the Caribbean

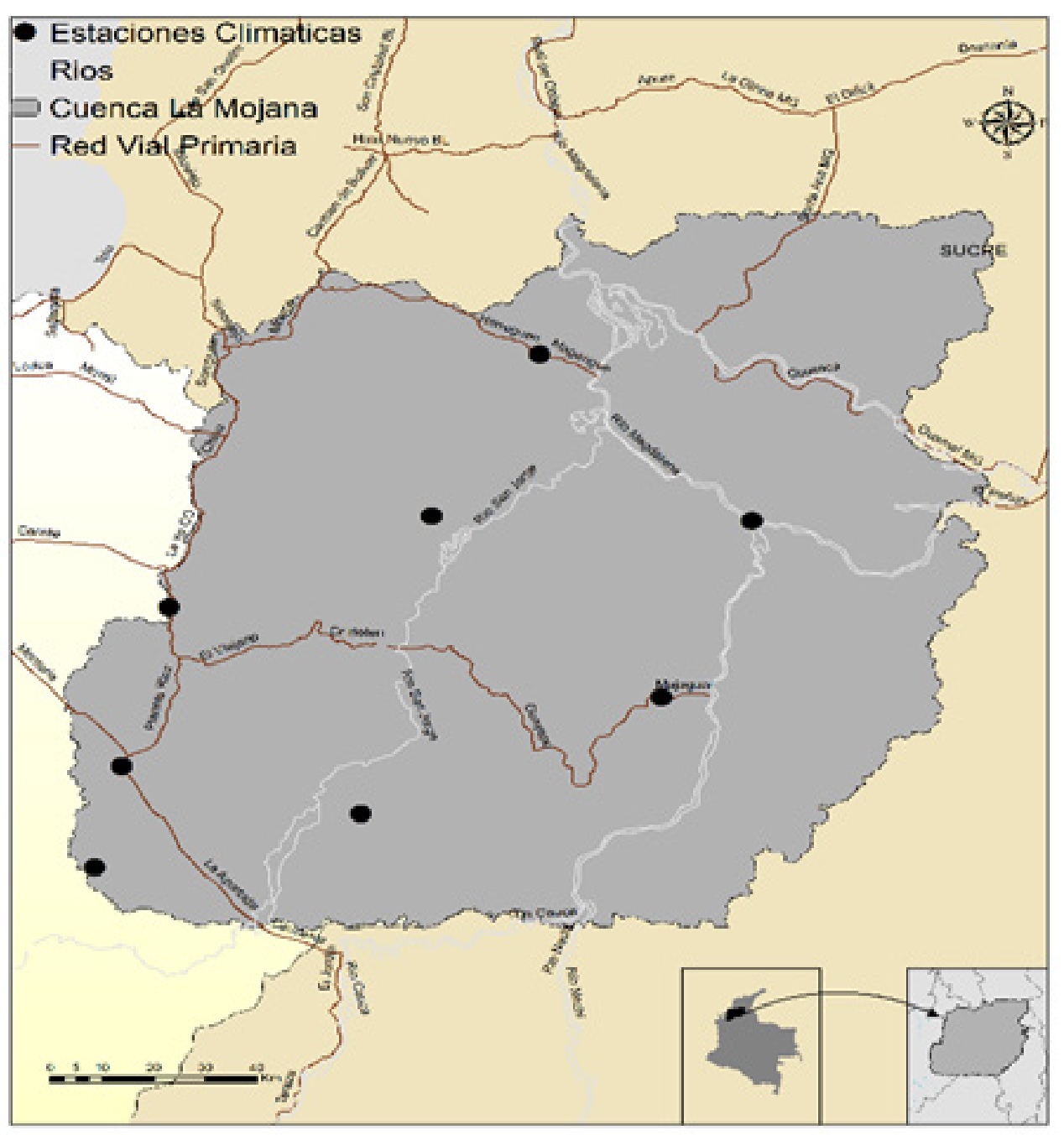

${ }^{\star}$ Climatic Stations ${ }^{\star}$ La Mojana Basis ${ }^{\star}$ Primary Road Network

Figure 1. Study area*. 
region on the north of Colombia, bounded on the east by the Cauca river, on the west by the San Jorge river and the Ayapel swamp, on the northeast by the Loba branch (Magdalena river) and on the south by the hill range of Ayapel. Geopolitically it is formed by the municipalities of Nechi (Antioquia), Magangue, San Jacinto del Cauca and Achi (Bolívar), Ayapel (Cordoba) and Guaranda, Majagual, Sucre, Caimito, San Marcos and San Benito Abad (Sucre), in the so-called Momposina Depression. The study area has 2,346,435.43 Ha, which obeys delimitation under the basin approach, on which the hydrological studies are based. Being this the reference study unit (Figure 1).

\subsection{Determination of the $\mathrm{CN}$}

$\mathrm{CN}$ assignment for the territory was made through the Arc CN-Runoff extension of ArcGIS developed by $^{30}$. Cover and land use file was requested for this in shape file format, obtained through the portals of the Environmental Information System of Colombia (SIAC) and the Geographic Information System for Planning and Land Management (SIGOT); similarly, textural classification file was obtained, from which the Soil Hydrological Group (GHS) was assigned, following suggestions from $\frac{6,10-12}{}$, taking the finer texture as a determinant in said categorization and considering it as limiting the infiltration. The cover and land use file was intersected with the GHS file, thus obtaining the curve number file; this $\mathrm{CN}$ result was taken to $\mathrm{AMC}_{\mathrm{III}}$, given that for the study area, the accumulated background precipitation in five days is greater than $53 \mathrm{~mm}$.

\subsection{Climate Analysis}

The climatic characterization is done under a global warming approach at local scale, following the methodology proposed by ${ }^{\underline{31}}$, consisting of the analysis of air temperature, atmospheric humidity and evapotranspiration of the soil-vegetation interface for a 39 years record period for eight climatic stations (Table 1) assigned to the catalog of stations of the Institute of Hydrology, Meteorology and Environmental Studies (IDEAM), surpassing the suggested by ${ }^{32}$ for climatic studies. Information provided by
IDEAM is subjected to a preliminary analysis using basic statistics to identify atypical and/or extreme data and verify quality of data. Then, the annual monthly totals are calculated, on which data completion will be carried out. Simple linear and simple mobile regressions are used for precipitation, calculating missing data by means of the resulting equation if meeting the minimum correlation criteria. Temperature and relative humidity are calculated using simple linear regression, simple mobile regression and mobile mean. Subsequently, resulting series is evaluated with the complete data by means of descriptive statistics and the completed one is validated by test runs, Helmert test and Spearman correlation. Next, the annual and multi-year averages are calculated, as appropriate for each variable and a trend analysis is carried out, thus, concluding global warming manifestation at the local scale.

Based on these results, indirect variables ( $\mathrm{dv}$ and ETP) are calculated using the expressions:

$$
d_{v}=\frac{t_{v}}{R_{v} T}
$$

Equation 7.

Being $\mathrm{T}$ the temperature $(\mathrm{K}), \mathrm{R}_{\mathrm{v}}$ the specific constant of water vapor $\left(461.8 \frac{J}{K g * K}\right)$, $\mathrm{t}_{\mathrm{v}}$ the atmospheric water vapor tension estimated by the expression ${ }^{33}$ :

$$
t_{v}=\frac{H R}{100} T_{s} \quad \text { Equation } 8 .
$$

$\mathrm{RH}=$ relative humidity; $\mathrm{T}_{\mathrm{s}}=$ saturated vapor tension calculated from the form:

$$
T_{s}=\exp \left(26,23-\frac{5416}{T}\right) \quad \text { Equation } 9 .
$$

$E T$ was estimated according to ${ }^{33}$ :

$$
E T P=16\left(\frac{10 t}{I}\right)^{a}
$$


Table 1. Climate stations

\begin{tabular}{|c|c|c|}
\hline Name & Latitude & Longitude \\
\hline Centro Alegre & $8^{\circ} 10^{\prime} 51^{\prime \prime} \mathrm{N}$ & $75^{\circ} 37^{\prime} 56^{\prime \prime} \mathrm{W}$ \\
\hline Baracoa Apartamento & $9^{\circ} 16^{\prime} 55^{\prime \prime} \mathrm{N}$ & $74^{\circ} 50^{\prime} 43^{\prime \prime} \mathrm{W}$ \\
\hline Ayapel & $8^{\circ} 27^{\prime} 42^{\prime \prime} \mathrm{N}$ & $75^{\circ} 09^{\prime} 52^{\prime \prime} \mathrm{W}$ \\
\hline Planeta Rica & $8^{\circ} 83^{\prime} 58^{\prime \prime} \mathrm{N}$ & $75^{\circ} 35^{\prime} 01^{\prime \prime} \mathrm{W}$ \\
\hline Pinillos & $8^{\circ} 14^{\prime} 41^{\prime \prime} \mathrm{N}$ & $74^{\circ} 27^{\prime} 28^{\prime \prime} \mathrm{W}$ \\
\hline Majagual & $9^{\circ} 42^{\prime} 34^{\prime \prime} \mathrm{N}$ & $74^{\circ} 38^{\prime} 09^{\prime \prime} \mathrm{W}$ \\
\hline Colomboy & $8^{\circ} 74^{\prime} 27^{\prime \prime} \mathrm{N}$ & $75^{\circ} 29^{\prime} 56^{\prime \prime} \mathrm{W}$ \\
\hline San Benito Abad & $9^{\circ} 09^{\prime} 50^{\prime \prime} \mathrm{N}$ & $75^{\circ} 02^{\prime} 41^{\prime \prime} \mathrm{W}$ \\
\hline
\end{tabular}

Being ET $=$ uncorrected evapotranspiration; $t=$ average monthly temperature; $a=$ power factor $(a=0.492+$ $\left.(0.179 * \mathrm{I})-\left(0.0000771 * I^{2}\right)+\left(0.000000675 * \mathrm{I}^{3}\right)\right)$ and $I=$ estimated annual heat index of the form:

$$
\begin{aligned}
& I=\sum_{i=1}^{12} i_{i} \\
& i=\text { monthly heat index. } \\
& i=\left(\frac{t_{i}}{5}\right)^{1.514}
\end{aligned}
$$

Equation 11.

Equation 12.

The Equation 8 result should be adjusted according to latitude and longitude, since there is a variation in the radiation incidence angle and thus, in the evaporation and transpiration.

Results obtained from $d_{v}$ and ETP, were subject to trend analysis and multi-year variation calculation from the linear trend equation calculated in excel.

\section{Results and Discussion}

\subsection{Cover, Land Use and Hydrological Condition}

The land cover and use file, obtained through SIGOT, was adjusted to the calculation hydrological conditions according to the calibration file in the use of the tool developed by ${ }^{30}$ for the use of these in the curve number maps generation.

The plant cover categorization types reported by IDEAM was generalized in seven main kinds, which correspond to the most representative of the study area, in which there is a predominance of grass covers and major areas dedicated to agricultural production, as well as secondary vegetation "stubble" type and important forest areas. Table 2 shows proportion in terms of extension of each cover generalized and categorized according to their hydrological condition corresponding to the calibration file of the ArcCN-Runoff tool in the classification and the fraction they occupy over the total land area. 
Table 2. Cover and land use

\begin{tabular}{|c|c|c|}
\hline Land Cover & Area (ha) & Fraction (\%) \\
\hline Bodies of Water & $227,940.82$ & 9.71 \\
\hline Secondary Vegetation & $120,863.38$ & 5.15 \\
\hline Urban Area & $5,531.08$ & 10.24 \\
\hline Forests & $246,279.18$ & 14.06 \\
\hline Crops & $329,923.62$ & 45.88 \\
\hline Pasture & $1,076,576.2$ & 14.46 \\
\hline Aquatic Vegetation & $339,203.8$ & 100.00 \\
\hline Total & $2,346,318.1$ & 10.50 \\
\hline
\end{tabular}

The bodies of water category represents the set of continental waters (swamps, reservoirs, rivers, streams, etc.), meanwhile, the secondary vegetation category is made up of shrubs and secondary vegetation "stubble" type; the forests category groups natural forests and tree plantations with characteristic forest canopy; the crop category includes those heterogeneous crop areas and mosaics of annual or transitory crops and permanent and semi-permanent crops; and finally, the aquatic vegetation corresponds to continental hydrophytes with presence in flood plains of the buffer zones of the different existing water bodies.

The above shows that succession of land cover does not favor initial abstraction processes carried out by plants since most of the territory is covered by grasses and aquatic vegetation, potentiating hydrological pressure, when considering the importance of this variable in the terrain hydrological response.

\subsection{Hydrological Soil Group (HSG)}

From the textural classification carried out by IDEAM and the IGAC (Agustín Codazzi Geographical Institute) obtained through SIAC-SIGOT and following the sugges- tion according to ${ }^{\underline{11}}$, the HSG was assigned considering the finer granulometric fraction due to the infiltration limiting characteristics ${ }^{34}$.

The predominant texture corresponds to frank textures with clay contents, whose granulometric distribution through the profile is moderately fine to fine (Table 3).

The CA-ZU category corresponds to surfaces covered by bodies of water and urban area respectively. According to Table 3, 37.06\% and $54.60 \%$ correspond to a HSG C and $\mathrm{D}$ respectively, implying that $91.66 \%$ of the total extension of the territory presents a natural vocation of limiting the infiltration.

\subsection{Curve Number (CN)}

Finally, interaction between vegetation cover and soil characteristics allow us to assign a $\mathrm{CN}$, expressing the affectation degree to the infiltration on the complex soil surface physical state, in which, the type of vegetation cover and the HSG allow calculating said affectation degree, an assertive indicator of the hydrological pressure in the territory. Results show (Table 4) that $92.3 \%$ of the total area presents CN greater than 80 , indicating that 2,165,016.18 Ha of land have an infiltration affectation greater than 
Table 3. Texture - HSG

\begin{tabular}{|c|c|c|c|}
\hline \multirow{2}{*}{ Texture } & \multirow{2}{*}{ HSG } & \multicolumn{2}{|c|}{ Area } \\
\cline { 2 - 4 } & & hectares & \% \\
\hline CA - ZU & B & $59,831.43$ & 0.11 \\
\hline Sandy Clay & D & $2,479.35$ & 5.92 \\
\hline Silty Clay & D & $138,923.32$ & 18.65 \\
\hline Clayey & A & $437,505.19$ & 0.03 \\
\hline Sandy & B & 698.79 & 3.75 \\
\hline Sandy loam & C & $88,047.54$ & 5.14 \\
\hline Loam & C & $120,585.73$ & 26.60 \\
\hline Clayey Sandy Loam & D & $380,920.05$ & 16.23 \\
\hline Clayey Silty Loam & D & $263,891.99$ & 11.25 \\
\hline Clayey Loam & B & $104,458.41$ & 4.45 \\
\hline Sandy Loam & C & $124,921.75$ & \\
\hline Silty loam & D & 3.52 & \\
\hline
\end{tabular}

$80 \%$; of that total, $34.7 \%$ have affectation between 80 to $89 \%, 48.2 \%$ present curve numbers between 90 and 94 and $17.1 \%$ present infiltration affectation greater than 95 in the area. On the other hand, $7.7 \%$ soil has a curve number between 50 and 80 . The previous evidence shows that land physical condition does not favor infiltration processes, thus, potentiating surface runoff.

The more detailed analysis shows the cover importance in the curve number when finding that, even when the soil vocation tends to present drastic limitations to the infiltration, which condition is represented in the HSG (expressed by the land granulometry); for the same HSG with different coverage (grass and forest as extremes), differences in $\mathrm{CN}$ are noted; being higher in the first case and indicating that coverage considerably influences $\mathrm{CN}$ and, therefore, the hydrological response for its role in the abstraction processes (initial abstraction mainly).

This highlights the $\mathrm{CN}$ as an indicator of the degree of land hydrological pressure when combining granulometric characteristics with the cover and condition of said cover. The latter being the most dynamic variable by anthropic intervention in different environments and for different uses linked to social, cultural and economic conditions.

\subsection{Climatology}

The average temperature is $28.2^{\circ} \mathrm{C}$, with significant fluctuations between $26.6^{\circ} \mathrm{C}$ and $30.3^{\circ} \mathrm{C}$. Regarding monthly behavior, two periods are identified with temperature peaks from December to April and from June to August, 
Table 4. Curve number

\begin{tabular}{|c|c|c|}
\hline Range & Area (ha) & Fraction (\%) \\
\hline $50-59$ & 41.47 & 0.002 \\
\hline $60-80$ & $181,260.48$ & 7.725 \\
\hline $81-89$ & $750,577.73$ & 31.990 \\
\hline $90-94$ & $1,043,542.38$ & 44.476 \\
\hline $95-100$ & $370,896.07$ & 15.808 \\
\hline Total & $2,346,318.13$ & 100.00 \\
\hline
\end{tabular}

coinciding with the low rainfall seasons for the area ${ }^{35}$. In these terms, there are two low temperature periods, first between April and June and second from September to November, where the maximum precipitation values are alternately presented. This last variable, unlike temperature, has a bimodal behavior, distinguishing a low rainfall season between December and March and a second season with high precipitation values for the rest of the year.

Nonetheless, fluctuations happen in the occurrence of events, in which avenues of greatest intensity are concentrated from April to June and from September to November, coinciding with the lower temperature values. In this regard, the area's average annual rainfall is $1,814.5 \mathrm{~mm}$. And in this aspect, there are also high value peaks of annual precipitation for the years 1996 and 2010, highlighting the occurrence of strong Nina events, which could interfere in the rainfall behavior for that period.

Figure 2 shows the air temperature behavior $(\mathrm{T})$ for climatic stations within the area, observing an increase trend from 1978 to 2016 . The period with the greatest increase for the set of stations is evident from the 90's decade, agreeing with the third report presented by the Intergovernmental Panel of Experts on Climate Change (IPCC) of the global temperature behavior ${ }^{22}$ and the reports at the national level $25,27,35$. The tendencies shown in Figure 2 allow us to qualitatively observe that during the study period, the temperature of the area has increased.
This behavior is individually expressed by each of the stations, implying that atmospheric thermodynamics very likely present variations that can alter not only the ecosystem equilibrium, but also involve changes in the local atmosphere along with significant alterations to the energy and hydrological balance.

On the other hand, even when the influence of oscillatory climatic phenomena referred as the Niño and Niña phenomena is considerable on the zone climatic variables ( $\mathrm{P}$ and $\mathrm{T}$ mainly) and reflected in the local atmosphere fluctuations; this behavior corresponds, in essence, to the natural climatic variability of the climate system, not reflecting changes over long periods; for which, based on the established by ${ }^{32}$, interannual trends show that local temperature behavior, analyzed according to historical records of a 39 years period reflects the global warming manifestation on a local scale.

The $d_{v}$ as an approximation to the local atmospheric thermodynamics, depending on temperature, varies proportionally, which in turn suggests that by retaining heat on the surface, it becomes a local heating coadjuvant, which conditions of low coverage do not favor the balance through the regulatory processes (hydrological and thermal) by abstraction. The $\mathrm{d}_{\mathrm{v}}$ presents a tendency to increase, because of the surface progressive warming indicating the phenomenon manifestation. Similarly, 


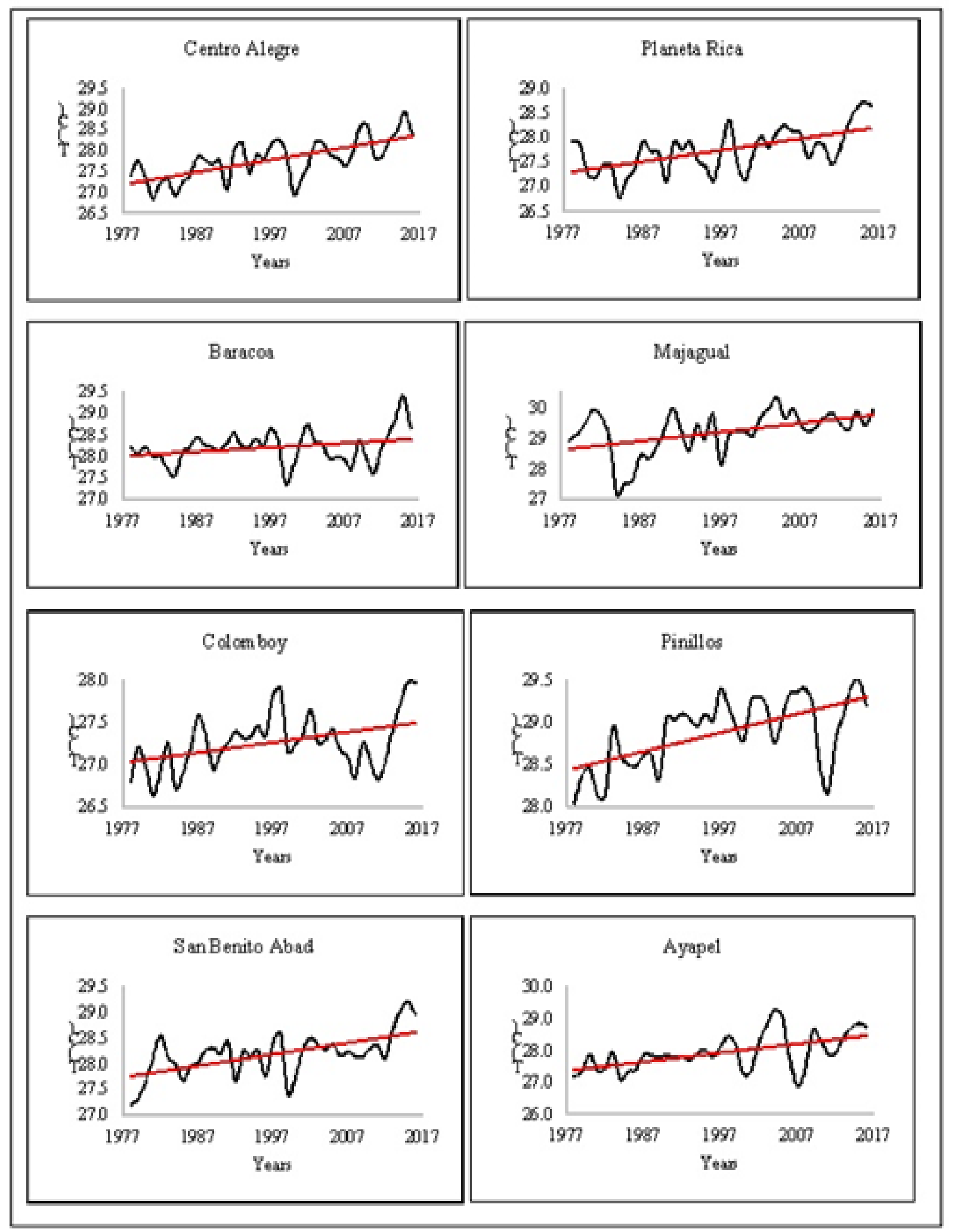

Figure 2. Multi-year variation of temperature. 
Table 5. ET and $d_{v}$ multiyear variation

\begin{tabular}{|c|c|c|c|c|c|c|}
\hline \multirow{2}{*}{ Station } & \multicolumn{3}{|c|}{ ET } & \multicolumn{3}{c|}{$\boldsymbol{d}_{v}$} \\
\cline { 2 - 7 } & $\dot{\mathbf{x}}(\mathbf{m m})$ & $\boldsymbol{\Delta}(\mathbf{m m})$ & $\Delta \%$ & $\dot{\mathbf{x}}\left(\mathbf{g ~ m}^{-3}\right)$ & $\Delta\left(\mathbf{g ~ m}^{-3}\right)$ & $\Delta \%$ \\
\hline Centro Alegre & 1421.5 & 25.5 & 1.8 & 21.4 & 1.1 & 5.2 \\
\hline Planeta Rica & 1394.3 & 34.4 & 2.5 & 21.7 & 0.3 & 1.5 \\
\hline Baracoa & 1415.3 & 52.6 & 3.7 & 21.8 & 0.8 & 3.5 \\
\hline Majagual & 1404.6 & 52.6 & 3.7 & 24.7 & 0.4 & 1.6 \\
\hline Colomboy & 1373.0 & 33.3 & 2.4 & 21.6 & 0.6 & 2.7 \\
\hline Pinillos & 1448.4 & 25.7 & 1.8 & 21.9 & 0.05 & 0.2 \\
\hline San Benito & 1418.1 & 122.1 & 8.6 & 22.1 & 1.0 & 4.4 \\
\hline Abad & 1466.4 & 58.8 & 4.0 & 22.2 & 1.3 & 5.8 \\
\hline Ayapel & & & &
\end{tabular}

potential evapotranspiration, as an approximation to the soil-vegetation complex, shows increasing trends.

According to the above, global warming manifestation at a local scale is identified, evidencing the impacts of climate change currently experienced by the globe. To quantitatively illustrate the increments of the variables described.

Table 5 shows the variations of ET and $\mathrm{dv}$, as a convincing argument of the previous statements, which, when considering surface physical state in terms of vegetation cover and influence on the territory hydrological pressure; makes it necessary to direct actions to adapt to climate change in a sustainable way with an exercise in planning and territorial management that optimizes the use of natural resources.

The quantitative analysis shows an average increase of $0.8^{\circ} \mathrm{C}, 50.6 \mathrm{~mm}$ and $0.7 \mathrm{~g} \mathrm{~m}^{-3}$ for air temperature, vapor density and potential evapotranspiration respectively, these conditions being unfavorable in the territory hydrological response. So, they exert a hydrological pressure in a natural way caused by the changes currently experienced by the local climate.

\section{Conclusions}

The current condition of La Mojana area presents high hydrological pressure expressed in high values of the Curve Number as a demographic indicator, in which, the cover and use of soil at $45.9 \%$ total area with pasture cover (generally, the cover that hydrological regulation favors the least) does not favor the hydrological regulation through the initial abstraction processes.

Local climate shows a tendency to increase in air temperature from 1978 to 2016, evidencing global warming manifestation on a local scale.

The area climate behavior increases the hydrological pressure degree by affecting the vegetation development conditions and the evaporation and transpiration relationships related to soil and vegetation. Local climate is strongly influenced by oscillatory phenomena (El Nino and La Nina). 
The curve number is an adequate indicator to express the hydrological pressure degree on a territory.

\section{Acknowledgements}

The authors show their expression of gratitude to the Corporation for the Sustainable Development of $\mathrm{La}$ Mojana and San Jorge "CORPOMOJANA".

\section{References}

1. Ferrer M, Rodriguez J, Estrela T. Generacion automatica del numero de curva con sistemas de informacion geografica. Ingenieria Del Agua. 1995 Dec; 2(4):43-58. https://doi. org/10.4995/ia.1995.2686

2. Monsalve G. Hidrologia en la Ingenieria. 2nd Ed. Ciudad de Mexico: Alfaomega; 1999. p. 1-358.

3. Hawkins RH, Ward TJ, Woodward E, Van Mullem JA. Continuing evolution of rainfall-runoff and the curve number precedent. 2nd Joint Federal Interagency Conference; Las Vegas: EE.UU; 2010. p. 1-12.

4. Michel C, Andreassian V, Perrin C. Soil conservation service curve number method: How to mend a wrong soil moisture accounting procedure? Water Resources Research. 2005 Feb; 41(2):1-6. https://doi.org/10.1029/2004WR003191

5. Soulis KX, Valiantzas JD. SCS-CN parameter determination using rainfall-runoff data in heterogeneous watershedsthe two-CN system approach. Hydrology and Earth System Sciences. 2012 Mar; 16(3):1001-15. https://doi. org/10.5194/hess-16-1001-2012

6. Diaz A, Mercado T. Determination of curve number in Betanci subwatershed (Cprdoba, Colombia) through remote sensing and GIS. Ingenieria y Desarrollo. 2017 Jul-Dec; 35(2):452-70. https://doi.org/10.14482/inde.35.2.10171

7. Romero P, Castro G, Gomez JA, Fereres E. Curve number values for olive orchards under different soil management. Soil Science Society of America Journal. 2007 Nov; 71(6):175869. https://doi.org/10.2136/sssaj2007.0034

8. Yuan Y, Nie W, McCutcheon S, Taguas E. Initial abstraction and curve numbers for semiarid whatersheds in Southeastern Arizona. Hydrological Processes. 2013 May; 28(3):774-83. https://doi.org/10.1002/hyp.9592

9. Woodward D, Hawkins R, Hjelmfelt A, Van Mullem J, Quan Q. Curve Number method: Origins, applications and limitations. USDA Natural Resource Conservation Service Conservation Engineering Division Technical Release 55; Washington. 2015.

10. Natural Resources Conservation Service (NRCS). Urban Hydrology for Small Watersheds, TR-55 NRCS. Urban
Hydrology for Small Watersheds TR-55. USDA Natural Resource Conservation Service Conservation Engineering Division Technical Release 55; Washington. 1986.

11. Natural Resources Conservation Service (NRCS). Small Watershed Hydrology: WinTR-55 User Guide. (N. R. C. Service, Ed.) (Service, N). USDA (United States Department of Agriculture): Washington. 2009.

12. Mongil J, Navarro J. Infiltracion y grupos hidrologicos de suelos en las laderas de los páramos (Valladolid). Cuadernos de Investigacion Geografica. 2012 Jan; 38(1):131-53. https://doi.org/10.18172/cig.1279

13. Ling L, Yusop Z. A micro focus with macro impact: Exploration of initial abstraction coefficient ratio $(\lambda)$ in Soil Conservation Curve Number (CN) methodology. IOP Conference. Series: Earth and Environmental Science. 2014; 18(1):8-13.

14. Correia F, Alvala R, Manzi A. Modeling the impacts of land cover change in Amazonia: A Regional Climate Model (RCM) simulation study.Theorical and Applied Climatology. 2008 Aug; 93(3-4):225-44. https://doi. org/10.1007/s00704-007-0335-z

15. Cambio climatico 2013: Bases de la ciencia física. 2014. http://www.aprendizajeverde.net/noticias/cambio-climatico-2013-bases-de-las-ciencias-fisicas.

16. Napoli M, Massetti L, Orlandini S. Hydrological response to land use and climate changes in a rural hilly basin in Italy. Catena. 2017. https://doi.org/10.1016/j.catena.2017.05.002

17. Chen M, Xie P, Janowiak JE. Global Land Precipitation: A 50-yr Monthly Analysis based on Gauge Observations. Journal of Hidrometeorology. 2002 Jun; 3:249-66. https:// doi.org/10.1175/1525-7541(2002)003<0249:GLPAYM>2.0 .CO;2

18. Adler RF, Huffman G, Chang A, Ralph F, Xie PP, Janowiak J, Nelkin E. The version-2 Global Precipitation Climatology Project (GPCP) monthly precipitation analysis (1979-Present). Journal of Hydrometeorology. 2003 Dec; 4:1147-67. https://doi.org/10.1175/15257541(2003)004<1147:TVGPCP>2.0.CO;2

19. Bates BC, Kundzewicz ZW, Wu S, Palutikof JP. El Cambio Climatico y el Agua. Documento tecnico del grupo Intergubernamental de expertos sobre el Cambio Climático. Secretaría del IPCC: Ginebra. 2008.

20. Tao F, Feng Z, Tang H, Chen Y, Kobayashi K. Effects of climate change, $\mathrm{CO} 2$ and $\mathrm{O} 3$ on wheat productivity in Eastern China, singly and in combination. Atmospheric Environment. 2017 Mar; 153:182-93. https://doi. org/10.1016/j.atmosenv.2017.01.032

21. Quevauviller P. Climate change policy and water resources in the EU and Spain. A closer look into the Water Framework Directive. Environmental Science and Policy. 2017; 69:112. https://doi.org/10.1016/j.envsci.2016.12.006 
22. Intergovernamental Panel on Climate Change (IPCC). Cambio climático 2001: La base científica: Contribución del grupo de trabajo I al tercer informe de Evaluación del Grupo Intergubernamental de Expertos sobre Cambio Climático. IPCC: Ginebra, Suiza; 2001. p. 1-101.

23. Solomon S, Qin D, Manning M, Marquis M, Averyt K, Tignor M, Chen Z. Cambio climático 2007: Base de ciencia física: Contribución del Grupo de Trabajo I al Cuarto Informe de Evaluación del Panel Intergubernamental sobre Cambio Climático. IPCC: Cambridge; 2007.

24. Gonima L, Perez M. Anlisis de la variabilidad climática de la temperatura del aire y de la ETP para una zona del Caribe Colombiano. Meteorología Colombiana. 2012 Dec; 1:183-95.

25. Ruiz J. Cambio climatico en temperatura, precipitacion y humedad relativa para colombia usando modelos meteorológicos de alta resolucion (panorama 2011-2100). IDEAM: Bogota, Colombia; 2010.

26. Calentamiento global en Colombia. Calentamiento Global en Colombia. 2011. http://www.bdigital.unal.edu. co/3673/1/gonzaloduqueescobar.201138.pdf

27. Ruíz J. Informe sobre el Cambio Climático en Colombia. IDEAM: Bogota, Colombia. 2013. p. 1-6.

28. Arango C, Dorado J, Guzman D, Ruíz F. Variabilidad climática de la precipitación en Colombia asociada al ciclo El Ni-o, La Ni-a-Oscilación del Sur (ENSO). Instituto de Hidrología, Meteorología y Estudios Ambientales (IDEAM): Bogota. 2015.

29. Perez M, Gonima L. El contenido del Vapor de agua de la atmosfera como indicador de calentamiento global en una zona del Caribe de Colombia. Cuadernos de Investigación Geográfica. 2014 Dec; 40(2):477-95. https:// doi.org/10.18172/cig.2517

30. Zhan X, Huang ML. ArcCN-Runoff: An ArcGIS tool for generating curve number and runoff maps. Environmental Modelling and Software. 2004 Oct; 19(10):875-9. https:// doi.org/10.1016/j.envsoft.2004.03.001

31. Perez M. Modelo metodologico para la identificación del calentamiento global a escala local: cuenca media y baja del rio Sinu. Universidad de Cordoba: Monteria, Colombia; 2015.

32. World Meteorological Organization (WMO). Guide to Climatological Practices WMO-No. 100. 1st edn. WMO: Genebra. 2011.

33. Fernandez F. Manual de climatología aplicada: Clima, medio ambiente y planificacion. 1st Ed. Mexico: SINTESIS; 2014.

34. Angelone S, Garibay MT, Cauhape CM. Geología y Geotecnia, permeabilidad de suelos. 1st Ed. Rosario, Argentina: Universidad Nacional de Rosario; 2006.

35. Instituto de Hidrologia, Meteorología y Estudios Ambientales (IDEAM). Atlas climatolpgico de Colombia. 1st ed. IDEAM and MAVDT: Bogota, Colombia; 2005. 